\title{
Analysis of algal growth- and morphogenesis- promoting factors in an integrated multi-trophic aquaculture system for farming Ulva spp.
}

\author{
Fatemeh Ghaderiardakani ${ }^{1}$, Gianmaria Califano ${ }^{2}$, Jan Frieder Mohr ${ }^{2}$, \\ Maria Helena Abreu ${ }^{3}$, Juliet C. Coates ${ }^{1}$, Thomas Wichard ${ }^{2, *}$ \\ ${ }^{1}$ School of Biosciences, University of Birmingham, Birmingham B15 2TT, UK \\ ${ }^{2}$ Institute for Inorganic and Analytical Chemistry, Jena School for Microbial Communication, \\ Friedrich Schiller University Jena, 07743 Jena, Germany \\ ${ }^{3}$ Travessa Alexandre da Conceiçao, ALGAplus Lda, Ílhavo 3830-196, Portugal
}

\begin{abstract}
The marine green macroalgal genus Ulva (Chlorophyta) requires the presence of a combination of regulatory morphogenetic compounds released by their associated epiphytic bacteria in addition to nutritional parameters. The activity of algal growth- and morphogenesispromoting factors (AGMPFs) derived from bacteria was determined in a land-based integrated multitrophic aquaculture (IMTA) system of fish and macroalgae (located at the coastal lagoon Ria de Aveiro, Portugal) using a standardised bioassay with axenic cultures of Ulva mutabilis during a snapshot study. The study thus informs aspects of various potential aquacultureenvironment interactions. It was observed that both the water from the lagoon (external to the farm system) and the water from the fish pond (input for algae cultures) could completely restore the normal growth and morphology of the macroalga under axenic conditions. The results highlight the presence of a sufficient chemical cocktail of AGMPFs in this IMTA system required for growth and morphogenesis of the sea lettuce Ulva spp. In addition, the water from fish farming increased the nutrient availability (nitrate and ammonium) needed for macroalgae production at low concentrations of metal contaminants. Interestingly, the abundances of known morphogenesis-inducing bacteria (e.g. Maribacter mutabilis, Sulfitobacter spp.) were enriched in the Ulva aquaculture water compared to the water from the lagoon. We thus conclude that sustainable growth and development of Ulva spp. can benefit from multitrophic aquaculture systems and shallow-water systems, due to the naturally enriched AGMPFs and their in situ production by bacteria in intensive algal aquacultures.
\end{abstract}

KEY WORDS: Algal growth- and morphogenesis-promoting factors - Aquaculture-environment interaction · Morphogens · Multitrophic aquaculture system · Seaweed · Waterborne compounds

\section{INTRODUCTION}

Marine species of the green macroalgal genus Ulva, belonging to the Ulvacean family, are common throughout intertidal and subtidal habitats worldwide. Massive algal blooms, particularly in nutrient-rich coastal waters, highlight the opportunistic nature of some Ulva species (Smetacek \& Zingone 2013, Mineur et al. 2015) which benefit from highly eutrophic coastal

${ }^{*}$ Corresponding author: thomas.wichard@uni-jena.de waters. Therefore, the genus Ulva is regarded as a reliable bio-indicator that responds to eutrophic water pollution (Kozhenkova et al. 2006). On the other hand, Ulva spp. cultures can also be utilised for bioremediation and extraction of nutrients from wastewater (Nielsen et al. 2012, Sode et al. 2013). Ulva spp. biomass sourced from green tides is used in high-volume markets (plant or animal care) (Fletcher 1996, Gao et al. 2017), but growing demand in human food

(C) The authors 2019. Open Access under Creative Commons by Attribution Licence. Use, distribution and reproduction are unrestricted. Authors and original publication must be credited. 
and other high-value applications is promoting Ulva production in aquaculture systems that can meet strict quality standards for e.g. the food industry (Abreu et al. 2014, Santos et al. 2015).

Similar to plant growth-promoting bacteria, which are microorganisms that naturally participate in complex ecological interactions (Liu et al. 2017), for example, in the rhizosphere with land plants, certain bacteria also induce growth and morphogenesis in macroalgae (Singh \& Reddy 2014, Wichard 2015). A cocktail of compounds, harbouring different ecophysiological effects, is involved in macroalgal development (Spoerner et al. 2012). Algal growth- and morphogenesis-promoting factors derived from bacteria (AGMPFs) induce cell division, cell wall formation, and holdfast development. AGMPFs are under investigation in several studies, particulary their ability to induce various morphogenetic changes across the prokaryote-eukaryote boundary (Wichard \& Beemelmanns 2018).

Members of Ulvaceae, like many other types of seaweed, harbour microbial biofilm communities on their surfaces with functions related to host growth and morphological development. Recent research has enabled a rapid expansion of knowledge focusing on many individual aspects of interactions between marine algae and their associated microbiota. Characterisation of the chemical interactions between microbiome and host (Goecke et al. 2010), the structuring of microbial communities on the surface of algal host (Burke et al. 2011), bacterial diversity (Lachnit et al. 2009, 2011, Barott et al. 2011), and algal pathogens and diseases (Gachon et al. 2017) have all been carried out.

In the absence of external delivery of growthpromoting morphogenetic factors from an appropriate bacterial community, germ cells (spores and gametes) of Ulva spp. develop into callus-like colonies consisting of undifferentiated cells with abnormal cell walls (Provasoli 1958, Spoerner et al. 2012, Grueneberg et al. 2016). Previous investigations have revealed the significant impact of the epiphytic bacterial community on the morphogenesis and have detailed the specificity of this interaction on the promotion of development in different Ulva species (Marshall et al. 2006, Spoerner et al. 2012, Wichard 2015, Ghaderiardakani et al. 2017). Spoerner et al. (2012) established a unique symbiotic tripartite system including 2 bacteria, Roseovarius sp. strain MS2 and Maribacter sp. strain MS6, working synergistically to induce complete morphogenesis in U. mutabilis through diffusible morphogens - Roseovarius-factor and Maribacter-factor - which induce cell division and cell differentiation, respectively. The established tripartite community was an essential step on the way to standardised laboratory cultures, providing controlled, repeatable conditions to study different aspects of algal-bacterial interactions (Wichard et al. 2015, Grueneberg et al. 2016).

Another designed community, introduced by Ghaderiardakani et al. (2017), resembled the tripartite Ulva mutabilis-Roseovarius-Maribacter system but employed $U$. intestinalis axenic gametes and pairs of bacterial strains isolated from species other than $U$. mutabilis and $U$. intestinalis. Although there is specificity in the bacterial signals regulating algal development (i.e. a signal inducing cell division and another signal for inducing rhizoid formation), there is no species-specificity among $U$. intestinalis, $U$. linza, U. pertusa, and U. mutabilis, as a range of bacteria was able to perform their eco-physiological functions similarly in all tested species (Singh \& Reddy 2014, Ghaderiardakani et al. 2017).

Grueneberg et al. (2016) screened a collection of sterile-filtered natural water samples collected from 20 sample sites and tidal pools across the lagoon Ria Formosa (Algarve, Portugal). The authors applied a bioassay-driven approach to examine the ecological relevance of waterborne bacterial morphogens by evaluating their morphogenetic impacts on the axenic gametes of $U$. mutabilis. The survey revealed that Ulva spp. could benefit from morphogenetic compounds with similar activity to the compounds released by Roseovarius sp. and Maribacter sp. (or equivalents of these strains) as diffusible waterborne morphogens were present in the water body. Based on these findings, beyond the eco-physiological implications, the morphogenetic inductive potential of filtered seawater has to be taken into account, particularly in the translation of this investigative research into practical outcomes (Grueneberg et al. 2016). Using filtered seawater in scientific investigations and even in commercial-size aquaculture (e.g. land-based aquaculture operations) may directly (positively) affect the success of biomass production due to its morphogenetic effect on the development of Ulva spp. (Grueneberg et al. 2016). Moreover, seawater composition can therefore also determine the growth, development, and hence bloom-forming activity of naturally occurring Ulva spp. populations.

In addition to the bacterial signals required for early Ulva spp. development, mature blade cells of $U$. mutabilis excrete regulatory factors into their cell walls and the environment. These factors, a glycoprotein (sporulation inhibitor [SI]-1) and a low molecular weight factor (SI-2), are essential for the mainte- 
nance of the vegetative state (Stratmann et al. 1996, Vesty et al. 2015) and are of great interest in algal aquaculture management (Charrier et al. 2017).

Integrated multitrophic aquaculture systems (IMTAs) mimic the normal functioning of marine ecosystems, where algae take up available dissolved inorganic nutrients (ammonium $\left[\mathrm{NH}_{4}{ }^{+}\right]$, nitrate $\left[\mathrm{NO}_{3}{ }^{-}\right]$, (ortho)phosphate $\left[\mathrm{PO}_{4}{ }^{3-}\right]$, and $\mathrm{CO}_{2}$ ) present in water discharged from aquatic animal production (Abreu et al. 2011). With the massive worldwide demand for food, sustainably farmed fish and macroalgae will play a crucial role in tackling this problem. Ulva spp. are currently used for food, nutraceuticals, feed functional additives, plant care, and are being investigated for novel biomaterials (e.g. bioplastics). Farmed biomass has the advantage of quality control and traceability; essential traits for its use in food and/or health products (Abreu et al. 2011, 2014, Patarra et al. 2017).

For successful controlled aquaculture involving Ulva species, and also for mitigation of nuisance blooms, a mechanistic understanding of the growth, development, and reproduction of Ulva species is required. Time-lapse studies of closed Ulva cultures have implied that sufficient $\mathrm{NO}_{3}{ }^{-}$concentration and the presence of SIs prevent sexual reproduction (Stratmann et al. 1996, Alsufyani et al. 2017). In this context, ALGAplus, a company involved with the production and trading of seaweed and derived products, has been able to continuously grow Ulva spp. biomass for long periods (over $18 \mathrm{mo}$ ) without the occurrence of massive sporulation events.

We hypothesised that the Ria de Aveiro lagoon, linked to the IMTA (see Fig. 1A), provides a reservoir of as-yet unidentified AGMPFs supporting Ulva spp. growth and development, while fish farming additionally enriches the water with nutrients. The enrichment of potentially morphogen-releasing bacteria was determined by microbiome analysis. The present study thus aimed to determine, at various sampling points of the IMTA (fish and macroalgae), the levels of waterborne morphogens, $\mathrm{NO}_{3}{ }^{-}, \mathrm{NH}_{4}{ }^{+}, \mathrm{PO}_{4}{ }^{3-}$, and metals, which can act as micronutrients or have a toxic effect, depending on their concentration.

\section{MATERIALS AND METHODS}

\subsection{Location, field site, and algal material in aquacultures}

The experiment was conducted at a 14 ha landbased/on-shore integrated fish and macroalgae farm operated by the company ALGAplus in the coastal lagoon Ria de Aveiro, Portugal (Fig. 1A). The openaquaculture system operates in the traditional way used in several locations throughout southern Europe, except for the innovative addition of the seaweed bioremediation component. Water flows in one direction only through a channel surrounding the farm, entering the production system (entrance ponds) at each high tide, passing through the fish ponds, and flowing back to the lagoon at low tides (from the sedimentation pond). Tidal gates control the water flow and level at each pond (entrance, fish, and sedimentation).

The fish farm $(2 / 3$ seabass and $1 / 3$ seabream in each pond) operates in a semi-intensive regime at a low production density (up to $2 \mathrm{~kg} \mathrm{~m}^{-3}$ ), with artificial feeding accounting only for $10-20 \%$ of the fish diet (natural food, such as crabs, shrimps, and algae account for the rest). Fish feeding typically occurs twice $\mathrm{d}^{-1}$, in early morning (before 08:00 h) and late afternoon (after 16:00 h).

The inorganic nutrients present in the fish ponds are the only nutrient source for the seaweed production at the ALGAplus farm. Thus, at the time of this study, the macroalgae system (ca. $620 \mathrm{~m}^{2}$ with max. $200001 \operatorname{tank}^{-1}$ ) received water pumped from the 2 fish ponds (no. 3 and no. 5; Fig. 1) that was mechanically filtered to remove particulate matter (drum filter with a mesh size $>40 \mu \mathrm{m}$ ) and then continuously distributed across the several seaweed tanks. Each seaweed tank was individually controlled regarding water exchange rates in order to minimise temperature variations and also nutrient availability. The algal species in cultivation was Ulva rigida, but some tanks are dedicated to the production of other green (Codium tomentosum) and red algae (Porphyra spp. and Gracilaria spp.). In this study, only algae tanks A and B with $U$. rigida were investigated. The outflow from all production units (i.e. ponds and tanks) was discharged to the sedimentation pond and thus mixed with the fish effluent before entering back to the lagoon (Fig. 1B).

For this study, 18 points were sampled across the IMTA farm (Fig. 1C, red dots). In February 2016, subsurface water was taken from each sample point at 4 times during the day $(09: 00,11: 00,14: 00$, and $17: 00 \mathrm{~h}$ ) to survey the morphogenetic activity induced by waterborne compounds as well as evaluate the $\mathrm{NH}_{4}{ }^{+}, \mathrm{NO}_{3}{ }^{-}$, and $\mathrm{PO}_{4}{ }^{3-}$ in the samples. At each sample site, $20 \mathrm{ml}$ water samples were collected with sterile screw cap polypropylene tubes (BD Falcon, Biosciences), transported immediately to the ALGAplus on-site laboratory, and filter-sterilised using $0.22 \mu \mathrm{m}$ pore size syringe filters into sterile 
A

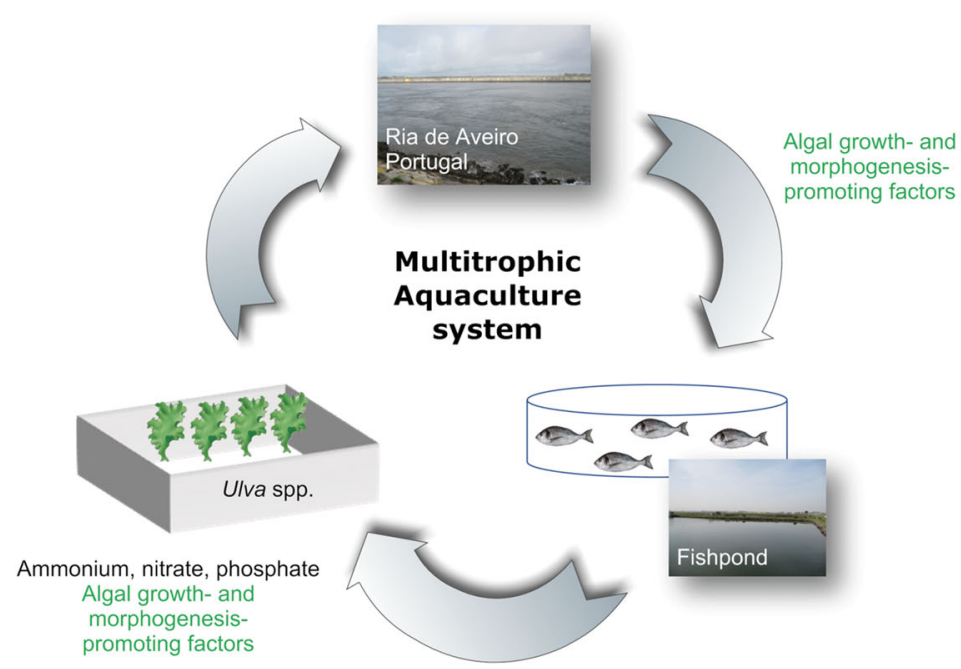

B

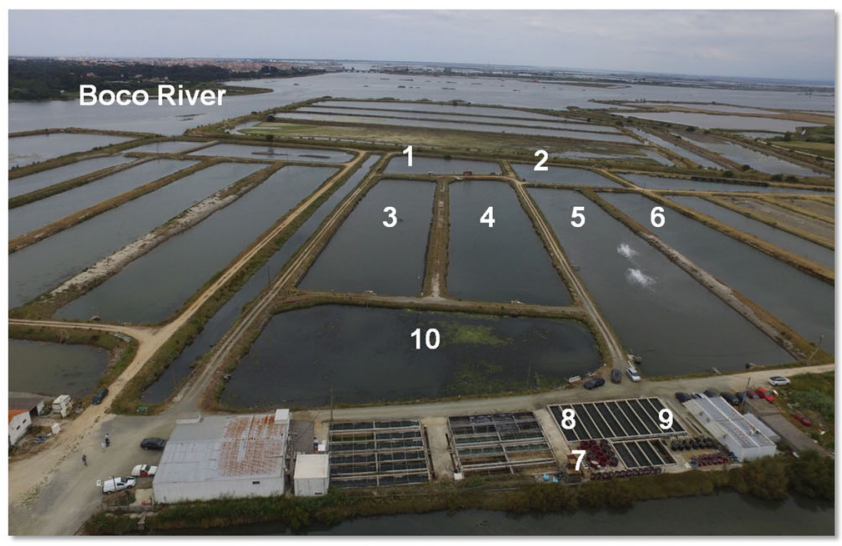

C

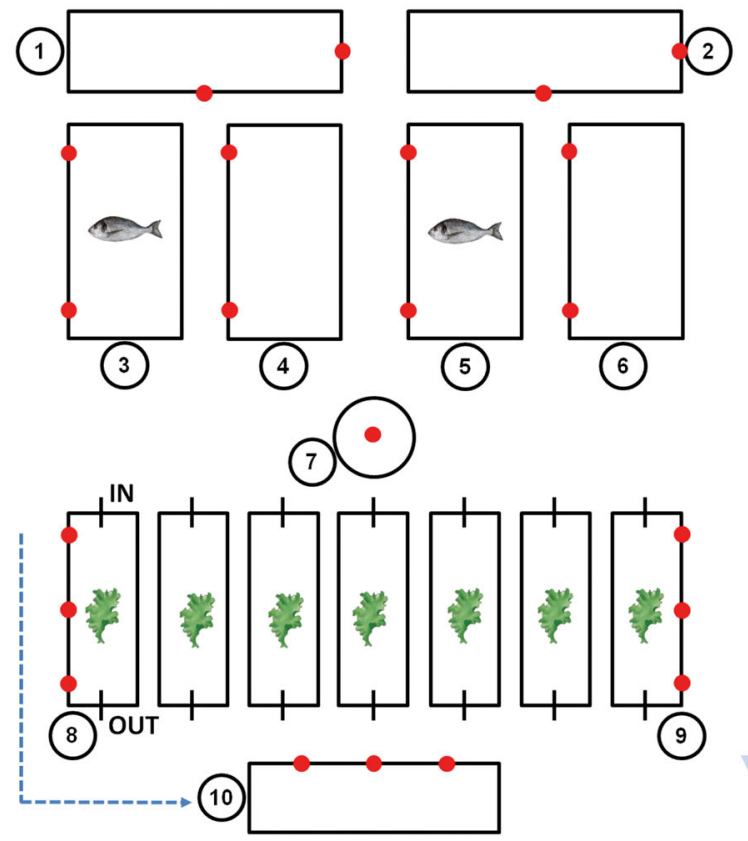

tubes under strictly sterile conditions within a laminar flow cabinet. The sterilefiltered water samples were frozen and stored at $-80^{\circ} \mathrm{C}$ for the morphogenesis bioassays. An aliquot from each sample was tested in the Ulva bioassay for morphogenetic activity and a second aliquot for levels of $\mathrm{NO}_{3}{ }^{-}$and $\mathrm{PO}_{4}{ }^{3-}$. Each assay was replicated 3 times for each sample; samples were taken from the ponds and tanks, as indicated in Fig. 1C (red dots). For example, in the case of algal tanks A and $\mathrm{B}$ (nos. 8 and 9 in the scheme), nutrients including $\mathrm{NH}_{4}{ }^{+}$were measured at the inlet, in the middle, and at the outlet of the pond. Ultimately, data from replicates taken within each pond, but also from ponds of the same type, were combined to calculate the mean and to produce the results (see Figs. 3, 5 \& 6) (i.e. entrance ponds nos. 1 and 2 [4 samples in total], fish ponds nos. 3 and 5 [4 samples in total], algal tanks A and B [6 samples in total], and the 3 discharge points of the algae system in the sedimentation pond [ 3 samples in total]; Fig. 1C).

\subsection{Algal material and cultivation under standardised laboratory conditions}

The Ulva species used for the lab-based bioassays of the water samples was the emerging model species $U$. mutabilis (Wichard et al. 2015). Haploid gametophytes from the naturally occurring developmental mutant of $U$. mutabilis named 'slender' (sl-G[mt+]) were used for all bioassays. Ulva samples resulted from the parthenogenetic development of gametophytes in the laboratory which had lost

Fig. 1. (A) Working hypothesis: algal growth- and morphogenesis-promoting factors are present in the lagoon water and can contribute to sustainable aquacultures. (B) Study site at the lagoon Ria de Aveiro. (C) Simplified scheme showing sampling points where water samples were collected at the multitrophic aquaculture system (red dots); water flows from entrance ponds through fish ponds to the algae tanks. Outflow from all production units (blue dashed line) is discharged to the sedimentation pond and thus mixed with the fish effluent before entering back to the lagoon 
their capability for spontaneous diploidization (Føyn 1959, Løvlie 1964, 1968).

U. mutabilis gametophytes were propagated in sterile culture flasks with gas-permeable screw caps (Nunc International) containing $100 \mathrm{ml}$ Ulva culture medium (UCM), prepared according to Stratmann et al. (1996), with freshly prepared axenic gametes (100 gametes $\mathrm{ml}^{-1}$; see Section 2.3) under standard growth conditions without additional aeration $(17 \mathrm{~h}$ light: $7 \mathrm{~h}$ dark regime at $18^{\circ} \mathrm{C}$ with an illumination of $60 \mu \mathrm{mol}$ photons $\mathrm{m}^{-2} \mathrm{~s}^{-1}$ provided by $50 \%$ GroLux, 50\% daylight fluorescent tubes; Wichard \& Oertel 2010).

\subsection{Preparation of axenic cultures}

For the preparation of axenic algal tissues, i.e. intact mature gametophytes of the fast-growing tubular mutant 'slender' U. mutabilis, were artificially induced to form gametangia by removal of at least 2 types of SIs via mincing and washing 3 times
(Stratmann et al. 1996). The gametangia were mature on the third morning, and swarming of the gametes was induced by changing the medium once more and exposing to light (Wichard \& Oertel 2010). Purification was performed by enabling the gametes' phototactic movement towards the light through a narrow horizontal capillary (under strictly sterile conditions). Concentrated gametes can be collected efficiently from the narrow light-exposed tip of the Pasteur pipette filled with sterile UCM. In general, this method needs to be repeated at least 3 times to obtain axenic gametes. As a final step, axenic gametes were routinely checked for axenicity by plating a drop of the 'gamete solution' on marine agar plates (Roth; supplemented with 1\% agar), by PCR amplification of the 16S rDNA (Spoerner et al. 2012, Wichard 2015) (Fig. 2A), and by observing the appearance of the algae (Grueneberg et al. 2016) (Fig. 2B).

The density of gametes in the axenic stock solution was measured by flow cytometry (BD Accuri ${ }^{\circledR}$ C6)
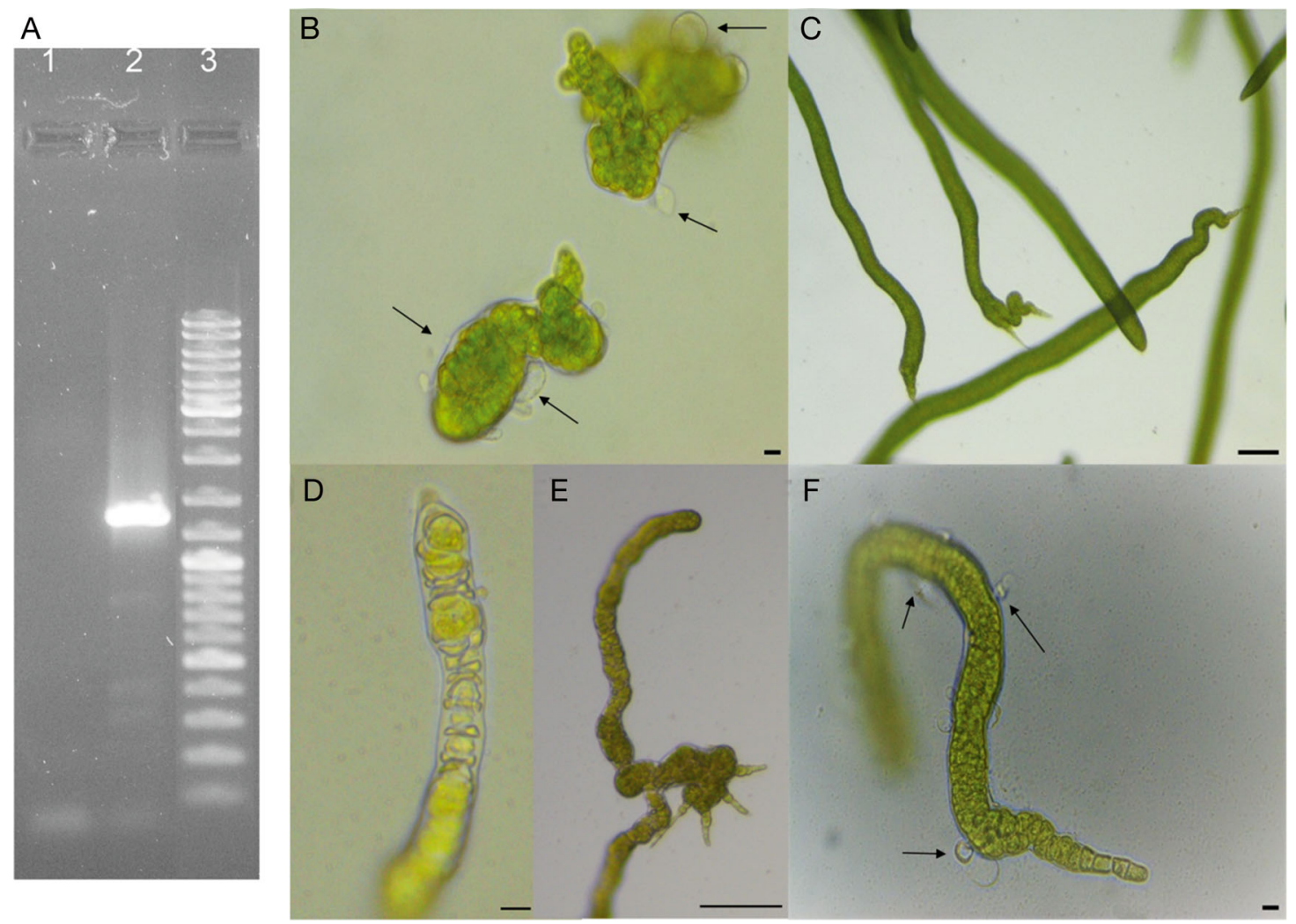

Fig. 2. Representative morphotypes within the Ulva tripartite community. (A) Demonstration of axenicity by amplification of a part of the 16S rDNA (520 bp) gene from the purified gamete stock solution (lane 1) and the non-axenic culture of $U$. mutabilis (lane 2). Lane 3 shows the gene ladder. (B-F) Using the 'Ulva bioassay array', AGMPFs were determined in sterile-filtered water samples collected from the IMTA system. (B) Axenic callus-like morphotypes of Ulva were compared with (C) axenic cultures inoculated with sterile-filtered water samples (see also Fig. 3A,B) after 3 wk. Controls show the morphotypes inoculated with $(\mathrm{D}, \mathrm{E})$ Maribacter sp. only or $(\mathrm{F})$ with Roseovarius sp. only. Arrows in $(\mathrm{B}, \mathrm{F})$ indicate the typical colourless protrusions from the exterior cell walls due to the lack of morphogens released by Maribacter sp. Scale bars $=(B, F)-10 \mu m ;(C-E)-100 \mu m$ 
before dilution to 300 gametes $\mathrm{ml}^{-1}$ in UCM and distribution in 96-well plates, $100 \mu \mathrm{l}$ in each well. Purified gametes were kept in the dark for $24 \mathrm{~h}$ to let them settle down to the bottom of plates at room temperature (Califano \& Wichard 2018).

\subsection{Determination of growth- and morphogenesis- promoting factors and nutrients}

To survey the prevalence of morphogenetic activities induced by waterborne compounds in the water samples from the aquaculture sites, a simplified, standardised bioassay using a 96-multiwell plate (Spoerner et al. 2012, Grueneberg et al. 2016). This 'Ulva bioassay array' enables monitoring of AGMPFs in natural aquaculture water samples under controlled conditions in the laboratory with many biological replicates and different dilution series, mainly because Ulva gametes can be obtained from several individuals of the same culture batch or even from a single individual Ulva specimen.

For testing the morphogenetic influence of the aquaculture water samples on Ulva gametes, UCM was replaced with the filter-sterilised water samples $(0.22 \mu \mathrm{m})$ (see Section 2.1). The bioassay array was operated with a dilution series of the collected samples using UCM to avoid nutrient deficiency over the time of the experiment. Dilution here refers to the total volume $(x /[x+y])$, where $x$ is equal to the parts of the collected aquaculture water and $y$ is equal to the parts of UCM. To minimise the differences between several experimental trials that would make the results ambiguous, positive and negative controls were applied to the same tested 96-well plates each time. $U$. mutabilis axenic gametes were incubated with Roseovarius sp. (MS2) alone, Maribacter sp. (MS6) alone, as well as with a combination of Roseovarius sp. and Maribacter sp. as positive controls. Negative (axenic) controls were Ulva gametes plus UCM alone developing into the typical callus-like morphotype (see Fig. 2B). In each given experiment, triplicates of each control were performed.

After inoculation of axenic gametes with sterile aquaculture water, plates were covered with a gaspermeable sealing film (Breathe-Easy; Diversified Biotech) and transferred to standard growth conditions (Wichard \& Oertel 2010).

Thallus development and morphogenesis of ca. 45-60 germlings in total for each type of pond and tank were examined in biological triplicates (15-20 germlings for each replicate) for each dilution step with $(1: 2,1: 10$, and 1:100 dilution) and time point
(09:00, 11:00, and 17:00 h). An inverted microscope (DM IL LED; Leica) equipped with a digital camera (Nikon) was used for inspection of the algal growth and morphogenesis. The qualitative features of inspected germlings in the tested population of Ulva included the presence of malformed cell walls (protrusion structures), cell divisions, blade formation, and differentiated rhizoid cells (Spoerner et al. 2012). After $10 \mathrm{~d}$, upon the first appearance of malformed cell walls in the negative (axenic) control, quantification of the average cell number of the growing germlings and the percentage of thalli with entirely normal cell walls were carried out. Averaged values were calculated from samples of the same pond- or tank-type of each dilution.

\section{5. $\mathrm{NH}_{4}{ }^{+}, \mathrm{NO}_{3}{ }^{-}$and $\mathrm{PO}_{4}{ }^{3-}$ measurements in the water from the aquaculture site}

For measurements of changes in soluble inorganic nutrients, photometric analyses were performed. The concentrations of $\mathrm{NO}_{3}{ }^{-}, \mathrm{PO}_{4}{ }^{3-}$, and $\mathrm{NH}_{4}{ }^{+}$were measured by a spectrophotometer (Thermo Fisher), using the colourimetric test kits VISOCOLOR ${ }^{\circledR} 211$ and SPECTROQUANT ${ }^{\circledR}$ (Macherey-Nagel) following the manufacturer's instructions (Maceda-Veiga et al. 2018).

\subsection{Inductive coupled plasma mass-spectrometry (ICP-MS) and atomic absorption spectroscopy (AAS)}

The content of $\mathrm{Cd}, \mathrm{Mn}, \mathrm{Mo}, \mathrm{Ni}$, and $\mathrm{Pb}$ was determined by ICP-MS using an Agilent 7500c ICP-MS system (Agilent) equipped with a Babington nebuliser, a Scott spray chamber (cooled to $2^{\circ} \mathrm{C}$ ), and a Fassel torch. For sample introduction, an ASX-500 autosampler (CETAC Technologies) was connected to the spectrometer with a $1.02 \mathrm{~cm}$ ID PVC tubing. For calibration, 8 standards were prepared by diluting a multi-element standard solution containing all described metals (Merck). As an internal standard, a mixture of yttrium $(\mathrm{Y})$ and cerium $(\mathrm{Ce})$ was added to all samples with a final concentration of $1 \mu \mathrm{g} \mathrm{l}^{-1}$ of both metals. The following isotopes were analyzed: $\mathrm{Cd}$ (111), Mn (55), Mo (95), Ni (60), Pb (208), Y (89), and Ce (140). Before measurement, samples $(0.2 \mathrm{ml})$ were diluted 10 times with ultrapure water and acidified with ultrapure $\mathrm{HNO}_{3}$ (Fischer Chemical) to a final acid concentration of $1 \%(\mathrm{v} / \mathrm{v})$. See Tables S1 \& S2 in the Supplement at www.int-res.com/articles/suppl/ q011p375_supp.pdf for a list of the parameters for ICP-measurements and calibration. 
Measurement of $\mathrm{Fe}$ and $\mathrm{Cu}$ was executed with a ContrAA700 atom absorption spectrometer (Analytik Jena AG) using electrothermal atomization. Transversely heated graphite tubes with PINplatform were used for all samples; signal evaluation was done by peak integration. Sample volume for measurement was $20 \mu$ l together with $5 \mu \mathrm{l}$ matrix-modifier containing $0.1 \%(\mathrm{~m} / \mathrm{v}) \mathrm{Mg}\left(\mathrm{NO}_{3}\right)_{2}$ and $\mathrm{Pd}\left(\mathrm{NO}_{3}\right)_{2}$. Parameters for AAS are listed in Table S2. For iron measurement, samples $(0.2 \mathrm{ml})$ were diluted 5 times by filling up $200 \mu \mathrm{l}$ sample to $1 \mathrm{ml}$ with ultrapure water containing $1 \%$ (v/v) $\mathrm{HNO}_{3}$ (Fischer chemical). For calibration, 2 calibration curves in the range of $0.5-5 \mu \mathrm{g} \mathrm{l}^{-1}$ were prepared by diluting stock solutions containing $1 \mathrm{~g} \mathrm{l}^{-1} \mathrm{Fe}$ and $\mathrm{Cu}$ (Merck) (Kügler et al. 2019).

\subsection{Microbiome analysis}

For sampling and sequencing, water (ca. 2 1) was collected from the Boco River and the aquaculture tanks ( $\mathrm{n}=4$ replicates site $^{-1}$ ) in April 2018, placed into a 31 plastic bag (Ziploc ${ }^{\circledR}$ ) and transported in a cold box $\left(4^{\circ} \mathrm{C}\right)$ to the laboratory. Under sterile conditions, each seawater sample was passed through sterile $0.22 \mu \mathrm{m}$ mixed cellulose ester membrane filters (Whatman ${ }^{\mathrm{TM}} / \mathrm{GE}$ Healthcare) using a vacuum pump. Under the same conditions, the filters were cut into small pieces and stored at $-80{ }^{\circ} \mathrm{C}$ until DNA extraction. Using the DNeasy ${ }^{\circledR}$ Power Soil ${ }^{\circledR}$ Kit (QIAGEN), DNA was isolated according to the manufacturer's protocol obtaining 8 samples; 4 replicates for the water of the lagoon (Boco River) and 4 for the aquaculture. The V4 hypervariable region (515-806) of the 16S rRNA gene was amplified at MR DNA (www.mrdnalab.com) using the primers 515F (5'GTG CCA GCM GCC GCG GTA A-3') (Caporaso et al. 2011) and 806RB (5'-GGA CTA CNV GGG TWT CTA AT-3') (Apprill et al. 2015). The sequencing was performed on an Illumina MiSeq platform to generate paired-end sequences of ca. $300 \mathrm{bp}$ in length sample $^{-1}$. The complete data set of $16 \mathrm{~S}$ rDNA sequences from the microbiota analyses of the lagoon and algae tank water (each $\mathrm{n}=4$ ) have been deposited at the European Nucleotide Archive (ENA) under the study 'PRJEB31839' with accession numbers ERS3334813-ERS3334816 (lagoon water) and ERS3334817-ERS3334820 (algae tank water).

Sequence data processing and analyses were performed using the QIIME 2 bioinformatic platform (Bolyen et al. 2019), the natural evolution of QIIME 1 (Caporaso et al. 2010). Raw reads 'fastq' files were converted with 'fastqprocessor' and imported into QIIME 2. Quality control was performed on demultiplexed sequences with 'DADA2' software (Callahan et al. 2016), which filters low quality and chimeric sequences and truncates the remaining sequences to $242 \mathrm{bp}$. With this step, sequences were grouped by $100 \%$ similarity generating unique exact amplicon sequence variants (ASVs). Using a pre-trained naive Bayes classifier on the SILVA database (Silva_132_99\% operational taxonomic units [OTUs] for V4 region 515-806) and the 'q2-feature-classifier' plugin (Pedregosa et al. 2011, Bokulich et al. 2018), taxonomy was assigned to ASVs. ASVs below $70 \%$ identity were considered as unclassified at the domain level and rejected from the final set of ASVs. From the ASV table, morphogenesis-inducing taxa were selected based on previous bioactivity tests including Pseudolateromonas and Alteromonas, which did not release morphogens (Grueneberg et al. 2016, Ghaderiardakani et al. 2017). The enrichment levels were compared within the same genera collected from water samples of algal tanks and the lagoon.

\subsection{Statistical analysis}

One-way ANOVA followed by a Tukey's post hoc test was performed for all analyses of $\mathrm{NO}_{3}{ }^{-}$and $\mathrm{PO}_{4}{ }^{3-}$ content to determine the significance of the difference between sampling sites. For statistical analysis of differences between measurements for AGMPFs and metals, a Kruskal-Wallis 1-way ANOVA followed by a Dunn's multiple comparisons test was performed. Here, a Gaussian distribution could not be assumed and thus the mean rank of each data set was compared with the mean rank of each other data set using GraphPad Prism v.7.00 (GraphPad Software). Dixon's Q-test was performed for the identification of outliers. Results for all statistical tests were considered significant at $\mathrm{p} \leq 0.05$.

\section{RESULTS}

To determine the levels of AGMPFs in the IMTA system, a 'snapshot' was taken at various time points over a single day, since Ulva spp. growth yields around $3 \mathrm{~kg}$ fresh weight $\mathrm{m}^{-2} \mathrm{mo}^{-1}$ with few variations over the year in this system (M. H. Abreu pers. obs.). This approach allowed us to determine many growth-promoting variables at the same time. The 
parameters measured were AGMPFs, vital nutrients, and metals.

\subsection{Algal growth- and morphogenesis-promoting factors (AGMPFs)}

Sterile-filtered water samples were tested to determine where and when morphogenesis-inducing compounds were present in the IMTA (Fig. 1B,C) using axenic cultures of Ulva mutabilis (Fig. 2A,B). The activity of morphogens within the test samples was assessed via a standardised bioassay array with U. mutabilis (Fig. 2B-F) by applying a dilution series of the collected samples with UCM (Grueneberg et al. 2016). Mean cell numbers and percentage of Ulva germlings with normal cell walls increased upon administration of sterile-filtered seawater from the aquaculture units (Figs. 2C \& $3 \mathrm{~A}, \mathrm{~B}$ ) indicating complete recovery due to the morphogenetic compounds in the water. Morphogenetic compounds could be even detected in excess in each water sample, as 1:2 diluted sterile-filtered water samples revealed a complete recovery of morphogenesis Ulva. Even 1:10 diluted samples showed significant induction of cell division (Fig. 3A) and the formation of a normal cell wall (Fig. 3B). The activities of the Roseovarius-factor (cell division) and the Maribacter-factor were not apparent in a dilution of 1:100 (Fig. 3A,B), when almost all gametes developed consistently into a callus-like morphotype typical of an axenic culture (Fig. 2B). The activity demonstrated both by the number of cells in individual germlings and the percentage of algae with normal cell wall formation did not significantly differ $(p>0.05)$ between the water samples at various collection points (Fig. 1C) or at different times of day in the IMTA (Fig. 3A,B). Importantly, the activities of the Roseovarius- and Maribacter-factors did not differ between the lagoon water ('entrance') and after the fish pond ('after filtration') (Fig. 3A,B). In summary, these results show that morphogenetic compounds were present in the used lagoon water, throughout the IMTA system, and throughout the day when the experiment was performed, in sufficient quantities to promote full morphogenesis of Ulva spp.

To determine the presence of potential morphogenproducing bacteria in Ulva spp. aquaculture, microbiome analysis was performed on water collected in the lagoon and algal tanks during an additional sampling. Seven taxa that have been shown to trigger growth and morphogenesis in Ulva spp. were present in the water of the algae tanks. In particular, bacteria of the genera Maribacter spp. and Sulfitobacter spp., known potential producers of morphogens (Grueneberg et al. 2016, Ghaderiardakani et al. 2017), were enriched. Roseobacter spp., Roseovarius spp., and Alteromonas spp. were not detected in the water samples collected in the lagoon (below the detection limit) but were detected in the algae tanks. Only Algoriphagus spp. $(p<0.05)$ and Pseudoalteromonas spp. were present in higher abundance in lagoon waters than in the algal aquaculture system (Fig. 3C).

\subsection{Dissolved nutrient levels across the farm}

Overall analysis showed a significantly lower concentration of $\mathrm{NO}_{3}{ }^{-}$and $\mathrm{PO}_{4}{ }^{3-}$ in the entrance pond compared to all the other sampling points (1-way ANOVA and Tukey's post hoc test, $\mathrm{p}<0.05$; Fig. 4A, B), but $\mathrm{NH}_{4}{ }^{+}$depletion occurred in the algae tanks ( $t$-test, $\mathrm{p}<0.05$ after removal of outliers; Fig. $4 \mathrm{C}$ ). Between the sampling points (fish ponds, algae tanks, and sedimentation pond), there was no difference in the levels of these nutrients, except for a slight decrease in the overall levels of $\mathrm{PO}_{4}{ }^{3-}$ registered in the algae tanks (Fig. 4A,B). $\mathrm{NO}_{3}{ }^{-}$levels tended to be higher in the measurements taken at 11:00 and 14:00 h (1-way ANOVA and Tukey's post hoc test, $\mathrm{p}<0.05$; Fig. 5A-D). Daily variation in $\mathrm{PO}_{4}{ }^{3-}$ was only observed in the fish ponds with a higher concentration after 11:00 h (Fig. 5E-H).

In detail, the Ulva production system effectively removed $\mathrm{NH}_{4}{ }^{+}$, between 0.087 and $0.071 \mathrm{mg} \mathrm{l}^{-1} \mathrm{~d}^{-1}$. The $\mathrm{NH}_{4}{ }^{+}$values were significantly different between the inlet and the outlet in both Ulva tanks (Fig. 4C). The measured removal efficiency of $\mathrm{NH}_{4}{ }^{+}$in algae tanks $\mathrm{A}$ and $\mathrm{B}$ was 65 and $49 \%$, respectively, whereas the concentration of $\mathrm{NO}_{3}{ }^{-}$and $\mathrm{PO}_{4}{ }^{3-}$ did not change between inlet and outlet in either algae tank (Fig. 4C). $\mathrm{NO}_{3}{ }^{-}$and $\mathrm{PO}_{4}{ }^{3-}$ were significantly higher in the fish ponds and in all subsequent sampling points compared to the entrance pond, which is connected to the Boco River (Fig. 4A,B), suggesting that a substantial proportion of the nutrients in the algal tanks originated from fish metabolism and organic feed provided in the morning and late afternoon.

In the entrance ponds (water sourced from the lagoon that supplies the fish ponds), $\mathrm{NO}_{3}{ }^{-}$levels peaked at 11:00 $\mathrm{h}\left(3.4 \mathrm{mg} \mathrm{l}^{-1}\right)$, with the lowest concentrations at 09:00 $\mathrm{h}\left(2.3 \mathrm{mg} \mathrm{l}^{-1}\right)$. This was lower than the subsequent locations (i.e. sampling sites), reflecting the fact that water entered from the high tide inflow and had not been exposed to the fish or feed on the farm. Similarly to $\mathrm{NO}_{3}{ }^{-}$, the $\mathrm{PO}_{4}{ }^{3-}$ content of the entrance ponds peaked at $14: 00 \mathrm{~h}\left(0.16 \mathrm{mg} \mathrm{l}^{-1}\right)$ and 
A
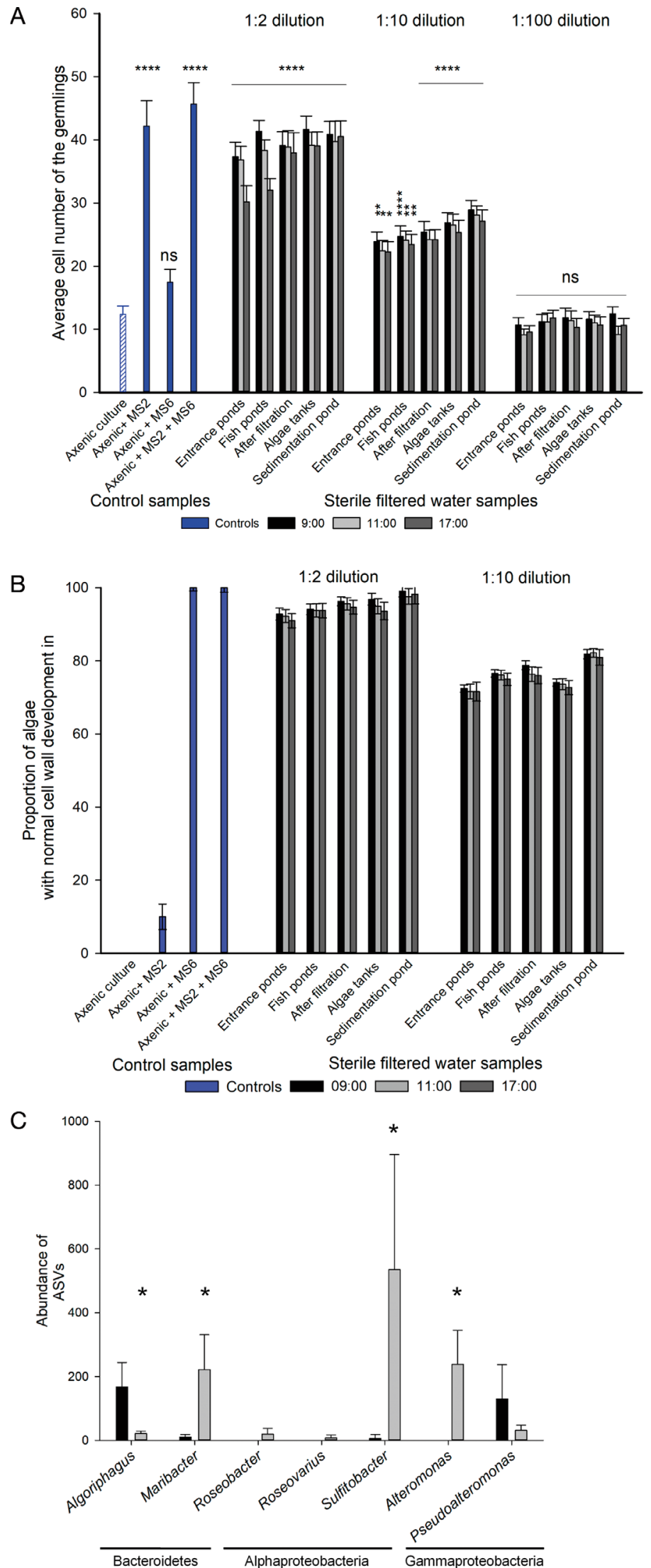

was lowest (the lowest across all sample sites) at 09:00 h (0.14 $\left.\mathrm{mg} \mathrm{l}^{-1}\right)$ (Fig. 5A,E).

In the fish ponds, $\mathrm{NO}_{3}{ }^{-}$peaked at $11: 00 \mathrm{~h}$ (average $\left.5.68 \mathrm{mg} \mathrm{l}^{-1}\right)$ and $\mathrm{PO}_{4}{ }^{3-}$ at 14:00 $\mathrm{h}\left(0.4 \mathrm{mg} \mathrm{l}^{-1}\right)$. This result might reflect that fish were fed at $07: 00-08: 00 \mathrm{~h}$, with subsequent digestion and excretion of nutrients occurring. The lowest amount of $\mathrm{NO}_{3}{ }^{-}$detected was at 17:00 h $\left(4.3 \mathrm{mg} \mathrm{l}^{-1}\right)$ and for $\mathrm{PO}_{4}{ }^{3-}$ at 09:00 h $\left(0.26 \mathrm{mg} \mathrm{l}^{-1}\right)$ (Fig. 5B,F).

In algae tanks $\mathrm{A}$ and $\mathrm{B}$, the $\mathrm{NO}_{3}{ }^{-}$concentration increased until 14:00 $\mathrm{h}\left(5.5 \mathrm{mg} \mathrm{l}^{-1}\right)$ and then decreased again at 17:00 h (Fig. 5C). No significant difference was measured compared to the $\mathrm{NO}_{3}{ }^{-}$concentration of the fish ponds. The overall $\mathrm{PO}_{4}{ }^{3-}$ concentration averaged $0.3 \mathrm{mg} \mathrm{l}^{-1}$ (Fig. 5G) and was significantly lower than in fish ponds (Fig. 4B).

In the sedimentation pond, where the outlet water of the algae tanks and the fish ponds was mixed by passing through the other tanks, the $\mathrm{NO}_{3}{ }^{-}$concentration was higher than in any other sampling site (Fig. 4A) and peaked at a level of $6 \mathrm{mg} \mathrm{l}^{-1}$ at 14:00 h (Fig. 5D).

\subsection{Metal analysis in water samples and algal tissue}

In addition to AGMPF and nutrients, metals can promote or inhibit algal growth. The concentration of 7 metals was measured in the water collected from

Fig. 3. 'Ulva bioassay array' of the morphogenetic activity of water samples from the aquaculture farm. (A) Potential AGMPFs released by bacteria using dilution series of the ratios $1: 2,1: 10$, and 1:100 of doubly sterile-filtered water samples on axenic $U$. mutabilis gametophytes. To estimate the activity of the Roseovarius-factor, the total cell numbers in thalli of $U$. mutabilis plantlets were counted $10 \mathrm{~d}$ after inoculation. Controls show the morphogenetic activity on gametes without bacteria (axenic), with Roseovarius sp., with the bacterial strain Maribacter sp., and in combination with both bacterial strains. Data were analysed using a Kruskal-Wallis test followed by a multiple comparisons test with Dunn correction for 'axenic culture' control versus treated groups. ${ }^{*} \mathrm{p} \leq 0.05 ;{ }^{* *} \mathrm{p} \leq 0.01 ;{ }^{* * *} \mathrm{p} \leq 0.001 ;{ }^{* * * *} \mathrm{p} \leq 0.0001$; ns: $\mathrm{p}>$ 0.05. (B) To determine the activity of the Maribacter-factor, the proportion of thalli of $U$. mutabilis with normal cell wall development was evaluated as a percentage of total thalli 10 $\mathrm{d}$ after inoculation with bacteria listed above as controls, with 1:2 dilution and 1:10 dilution. The effect of the Maribacter-factor completely vanished at 1:100 dilutions (i.e. $0 \%$, not shown). Error bars in (A) and (B) represent confidence intervals ( $p=0.95 ; n=45-60$ ind. algae). (C) The enrichment of selected bacterial genera in algae tanks (grey bars) or lagoon waters (black bars) was estimated by the abundance of the amplicon sequence variants (ASV). Significant differences are indicated by an asterisk $\left(t\right.$-test $\left.{ }_{i}{ }^{*} p \leq 0.05\right)$. Error bars: $\mathrm{SD}(\mathrm{n}=4)$ 
A

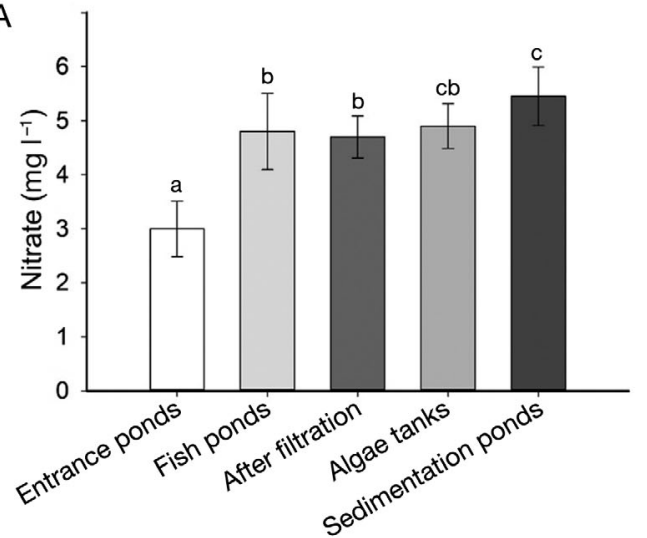

B

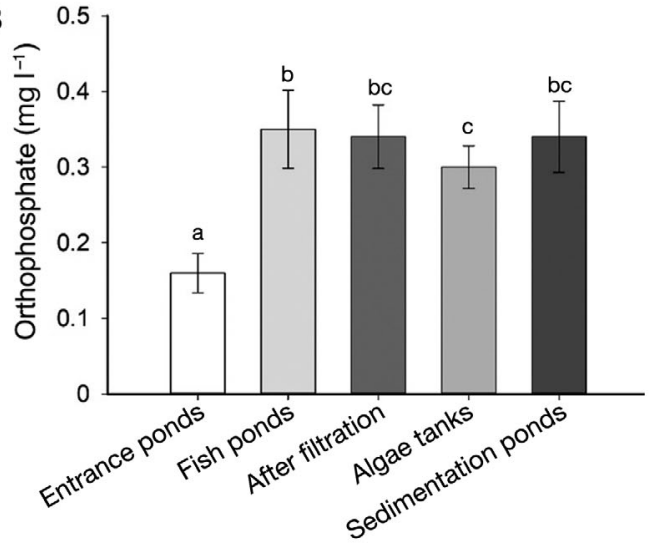

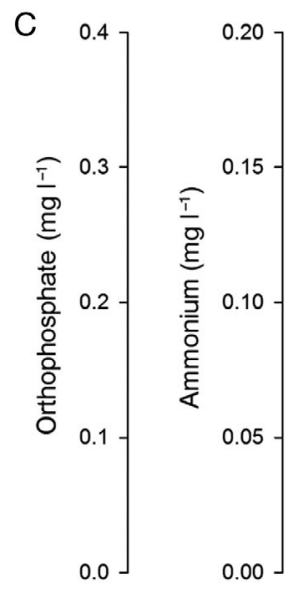

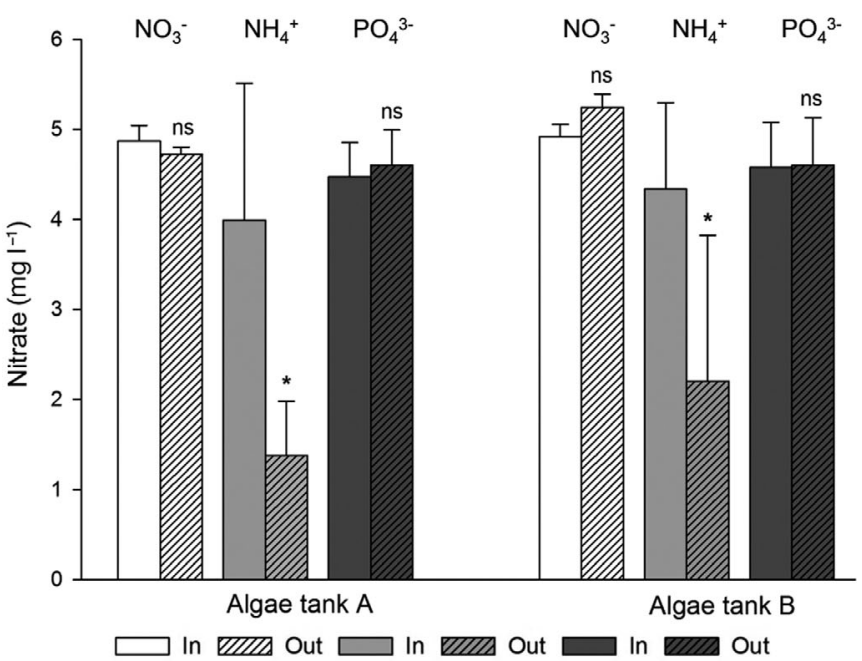

Fig. 4. Mean (A) nitrate $\left(\mathrm{NO}_{3}{ }^{-}\right)$and (B) orthophosphate $\left(\mathrm{PO}_{4}{ }^{3-}\right)$ concentrations measured over the $1 \mathrm{~d}$ of sampling and compared with the water from the entrance pond. A 1-way ANOVA was performed to reveal statistically significant differences (B,C), followed by Tukey's post hoc comparisons tests. Groups which do not share the same letter are significantly different ( $\mathrm{p} \leq 0.05)$. Error bars: confidence intervals $(\mathrm{p}=0.95 ; \mathrm{n}=8)$. (C) Comparison of the mean concentration of ammonium, $\mathrm{NO}_{3}{ }^{-}$, and $\mathrm{PO}_{4}{ }^{3-}$ in the algae tanks A and B measured at the input and output of the pond. After removal of outliers, significant differences were identified $\left(t\right.$-test, $\left.{ }^{*} \mathrm{p} \leq 0.05, \mathrm{n}=4\right)$. The variance of the complete data set is shown (mean $\pm \mathrm{SD}$ )

different locations of the IMTA. These were chosen to take into account food safety directives used for algae in some European Union countries. Metal concentration ranges in the water across all samples were as follows (all in $\mu \mathrm{g} \mathrm{l}^{-1}$ ): $\mathrm{Cd}$ : 0.027-0.039; $\mathrm{Cu}$ : 0.49-1.39; Fe: 5.10-17.21; Mn: 5.56-12.81; Mo: 6.04-10.04; Ni: 3.0-9.80; and $\mathrm{Pb}: 0.08-0.35$. In the water, only traces of $\mathrm{Pb}$ and $\mathrm{Cd}$ were detected (Fig. 6). Whereas the concentrations of $\mathrm{Cd}, \mathrm{Mn}, \mathrm{Mo}, \mathrm{Ni}$, and $\mathrm{Pb}$ did not change in the IMTA, the elevated amount of Fe appeared to drop by half after filtration. However, this change was not statistically significant due to the lack of Gaussian distribution of this data set (Fig. 6). Conversely, the concentration of dissolved $\mathrm{Cu}$ increased in the fish ponds, but not in a statistically significant manner (Fig. 6A,B). All determined metal concentrations were below the recommended values of the WHO (WHO 2008).

\section{DISCUSSION}

Seaweed aquaculture, alone or integrated into animal production, requires a fundamental understanding of the underlying biological mechanisms controlling macroalgal life cycles, from the generation of germ cells to the growth and fertility of the adult organisms (Charrier et al. 2017). In this study, the input water to the farm from the surrounding lagoon (Ria de Aveiro) as well as several points within the IMTA system itself were analysed for the activity of bacterial signals (not yet structure-elucidated) required for Ulva's develop- 

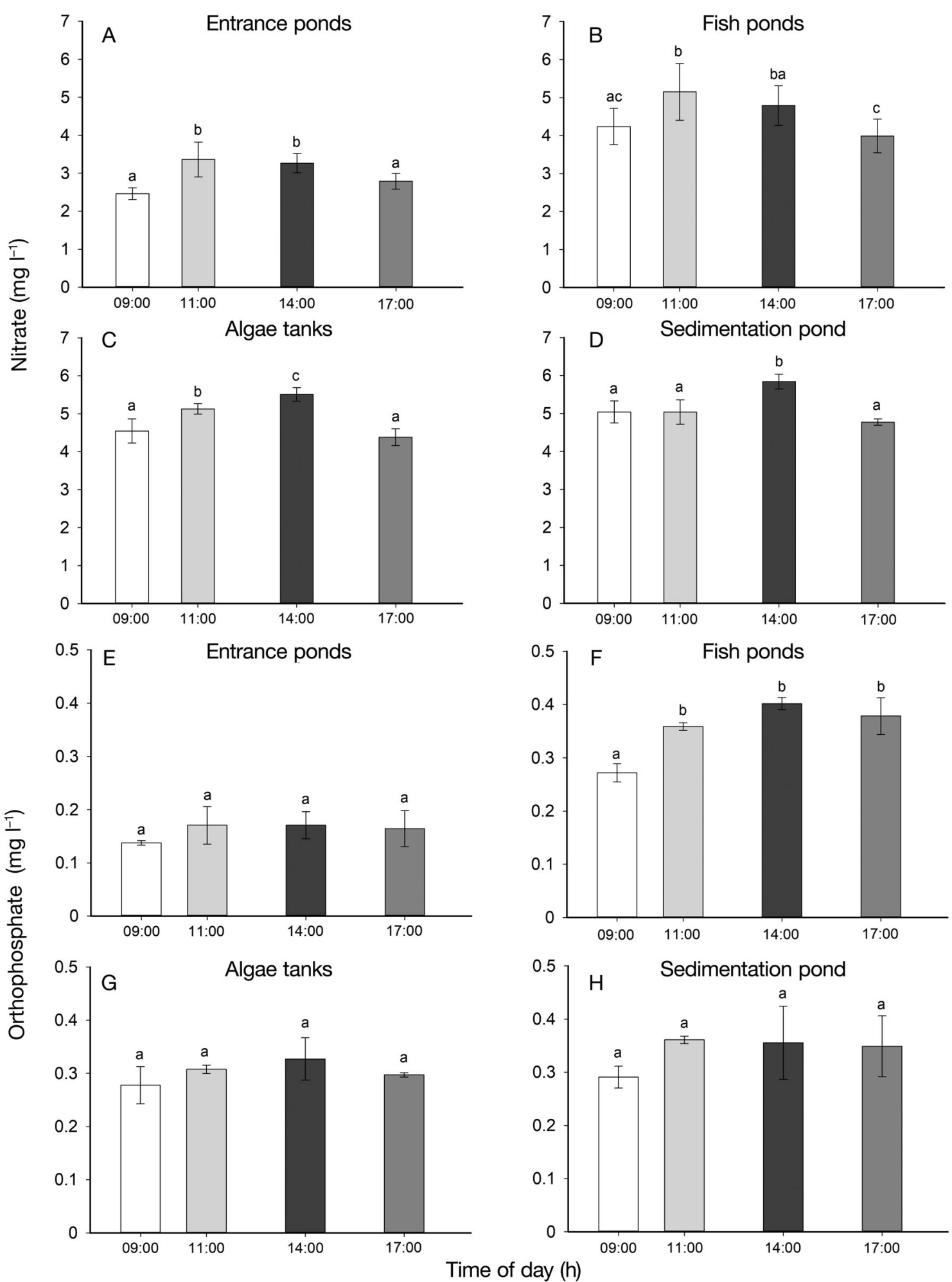

Fig. 5. Comparison of the concentration of nitrate $\left(\mathrm{NO}_{3}{ }^{-}\right)$and orthophosphate $\left(\mathrm{PO}_{4}{ }^{3-}\right)$ along with the sampling site; values display the mean of $\mathrm{NO}_{3}{ }^{-}$and $\mathrm{PO}_{4}{ }^{3-}$ concentrations in (A) entrance ponds 1 and 2, (B) fish ponds 1, 2, 3 and 4, (C) after filtration of the water, and in (D) algae tanks. Average of $\mathrm{PO}_{4}{ }^{3-}$ concentrations in (E) entrance ponds 1 and 2, (F) fish ponds 1, 2, 3 and 4, (G) algal tanks and $(\mathrm{H})$ sediment pond. A 1-way ANOVA was performed to reveal statistically significant differences, followed by Tukey's post hoc comparisons tests. Groups which do not share the same letter are significantly different $(p \leq 0.05)$. Error bars: confidence intervals ( $\mathrm{p}=0.95 ; \mathrm{n}=3-8)$ 


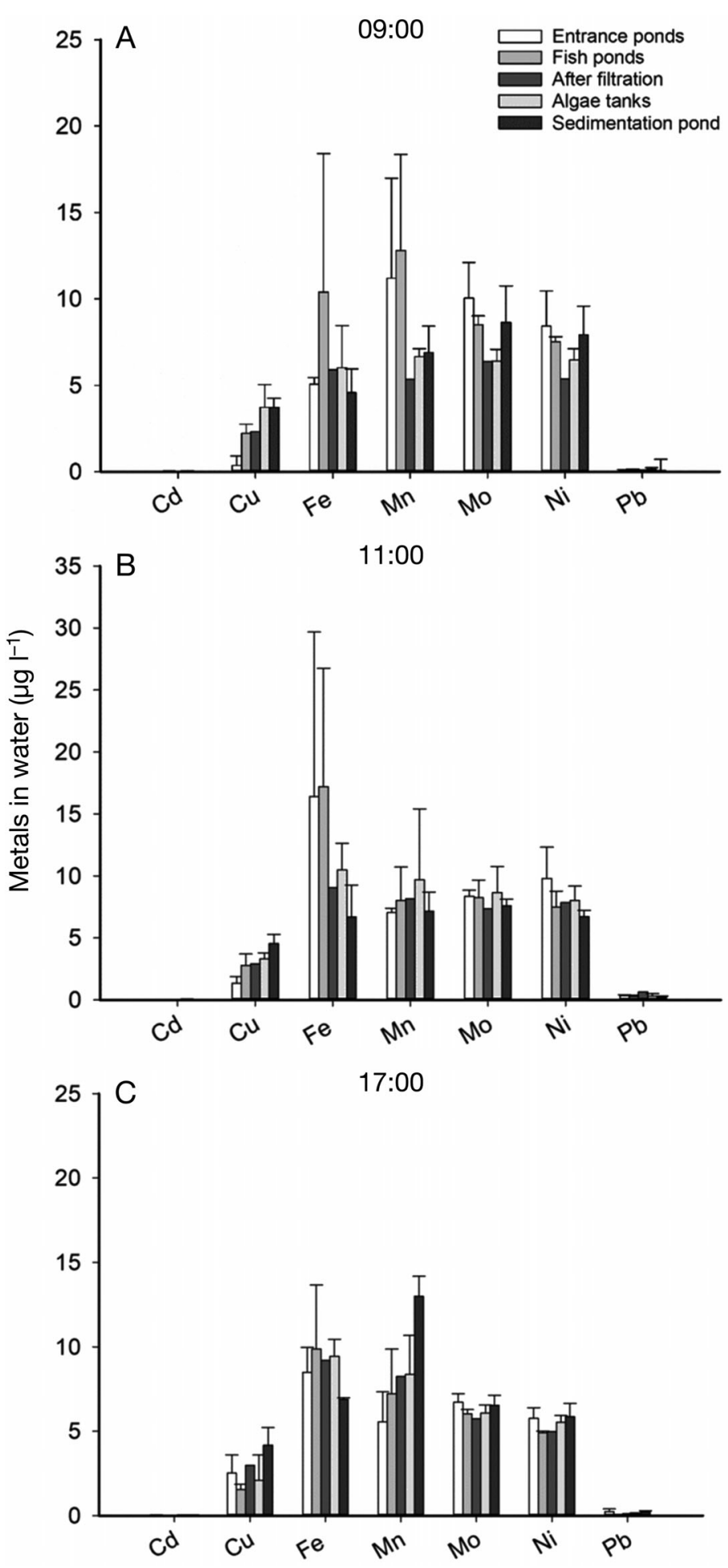

Fig. 6. Changes in heavy metal contents in seawater at the sampling site of the IMTA. Values display the average of metal concentrations in seawater of the ponds at the entrance, the fish ponds, the algae tank, and the sediment pond at (A) 9:00 h, (B) 11:00 h and (C) 17:00 h. Data were analysed using a Kruskal-Wallis test followed by a multiple comparisons with Dunn's test indicating no significant differences between the ponds. Error bars: SD $(n=3)$ ment and morphogenesis, in addition to nutrients and metals. Our current data present a $1 \mathrm{~d}$ snapshot of relevant AGMPFs, nutrients, and metals for land-based IMTAs.

\subsection{Water from the lagoon and aquaculture system promotes complete morphogenesis}

Sterile-filtered aquaculture water samples positively affected the growth, development, and morphology of axenic $U$. mutabilis gametes positively (Figs. 2C \& $3)$. This demonstrates the presence of the activity of morphogenetic compounds that have also been determined in tidal pools and in the lagoon water of the Ria Formosa (Portugal), where the shallow water body is separated from a more substantial body of water by barriers (Grueneberg et al. 2016). Our semi-quantitative data indicates that the aquaculture water can initiate growth and morphogenesis of axenic germlings through released morphogenetic compounds present in excess, but the identity of those compounds, most likely originating from bacteria, must still be determined (Wichard \& Beemelmanns 2018). In this context, Matsuo et al. (2005) reported the potentially important role of thallusin for the normal development of Monostroma oxyspermum. Thallusin was also suggested to be bioactive against Ulva spp. (Wichard \& Beemelmanns 2018, T. Wichard unpubl. data). Even diluted samples provided the morphogenetic activity for the recovery of morphogenesis. These results also support earlier investigations that direct cell-cell-contact with bacteria is not essential for triggering morphogenesis in Ulva spp. (Matsuo et al. 2003, Marshall et al. 2006, Spoerner et al. 2012).

The prevalence of AGMPFs phenocopied the activities of the Roseovarius- and Maribacter-factors (Spoerner et al. 2012, Weiss et al. 2017) in water samples of the studied IMTA. The AGMPFs can thus sustainably support the development of Ulva spp. plantlets. Interestingly, the dilution series influenced the reactions of the AGMPFs to varying degrees (Fig. 3A,B), which indicates 2 different molecular mechanisms for the 2 AGMPFs. When the concentration of the Maribacter-factor was decreased by dilution (Fig. 3B), the phenotype of some individuals indicated that the Roseovarius-factor solely controlled them, as protrusions could be observed (similar to those in Fig. 2F). Further studies are certainly needed to monitor and ideally to identify the underlying molecular structure of the AGMPFs throughout the season.

Overall, there was no significant difference in the activity of each of these potential AGMPFs between 
the entrance pond and fish ponds, indicating that fish farming does not jeopardise the positive effect of the lagoon water by removing or blocking the activity of beneficial morphogens. The lagoon can thus provide a reservoir of those compounds; this might explain in part the success in producing Ulva spp. cultures on this site. AGMPFs from the lagoon water might, therefore, be considered a naturally occurring boosting parameter of Ulva growth in land-based aquacultures and commercial-sized intensive systems, leading finally to increased yield of algal biomass.

It has been suggested that Ulva spp. 'garden' their microbiome (Kessler et al. 2018), and therefore may select essential surface AGMPF-producing bacteria. Indeed, the microbiome enrichment analysis in the algae tanks supports this assumption, as the abundance of key genera such as Maribacter and members of the Roseobacter clade (such as Sulfitobacter spp.) was significantly increased compared to the lagoon water (Fig. 3C). Conversely, Pseudoalteromonas spp., which do not release morphogens (Grueneberg et al. 2016), were not enriched in the water of the algal aquaculture.

In our study, we mainly considered the sequences of those bacteria that previously showed morphogenesisinducing bioactivity and used Pseudoalteromonas spp. as a negative control. However, further detailed analysis of the data (ENA-Study PRJEB31839) might reveal the presence of previously undetected taxa associated with Ulva spp. which possess unknown functional traits - such as Alteromonas spp., whose abundance was higher in the algae tanks than in lagoon water, but did not release AGMPFs (Grueneberg et al. 2016). In particular, Algoriphagus is an exciting genus for further studies of adverse and beneficial algae-bacteria interactions. Overall, we conclude that morphogens can be provided by in situ bacterial proliferation in the algae tanks.

\subsection{Fish-farming water increases the nutrients requiered in macroalgal production}

Sea lettuce Ulva spp. has been identified as an ideal candidate for biofiltering fish pond effluents. IMTAproduced seaweed has generally shown higher productivity levels compared to seaweed from the natural environment due to the continuous steady supply of nutrients (Shpigel et al. 2017). $\mathrm{NH}_{4}{ }^{+}$, excreted by fish, is the preferential $\mathrm{N}$-source compared to $\mathrm{NO}_{3}{ }^{-}$for many algae, since $\mathrm{NH}_{4}{ }^{+}$can be directly assimilated into amino acids and, in contrast to the oxidized $\mathrm{N}$ forms of $\mathrm{NO}_{3}{ }^{-}$and nitrite, it does not need to be reduced prior to amino acid synthesis (Gualtieri \& Barsanti 2006, Ale et al. 2011). $\mathrm{NH}_{4}{ }^{+}$is also the most common $\mathrm{N}$ form in fish farms, especially in intensive systems. In contrast to $\mathrm{NH}_{4}{ }^{+}$, which decreases by $~ 50-60 \%$ across the algae tanks from the inlet to the outlet (Fig. 4C), the variations seen in $\mathrm{NO}_{3}{ }^{-}$and $\mathrm{PO}_{4}{ }^{3-}$ before and after the algae tanks are not significant.

Differences between sampling locations were most apparent when comparing the entrance ponds to all other ponds (Fig. 4B,C). In this system, the fish were fed in the early morning (approx. 07:00 h) and late afternoon (15:00-16:00 h); thus, the variations in $\mathrm{N}$ measured are in agreement with Echevarréa et al. (1993), who reported that dissolved inorganic nutrients $\left(\mathrm{NH}_{4}{ }^{+}\right.$and $\left.\mathrm{NO}_{3}{ }^{-}\right)$peaked in the water of the studied algal cultures between 2 and $6 \mathrm{~h}$ after feeding time. In the entrance ponds, where the water was collected from the lagoon, the slight variations in $\mathrm{NO}_{3}{ }^{-}$and $\mathrm{PO}_{4}{ }^{3-}$ concentrations during the day (Fig. 5) were likely due to a combination of the tidal regime and horizontal currents of the nutrient-rich waters in the lagoon.

Our results support previous work showing the importance of $\mathrm{NH}_{4}{ }^{+}$uptake in Ulva spp. Ale et al. (2011) reported a favourable growth response to $\mathrm{NH}_{4}{ }^{+}$relative to other $\mathrm{N}$ sources by monitoring the growth kinetics of U. lactuca (Ale et al. 2011). Although the favourable growth response to $\mathrm{NH}_{4}{ }^{+}$as the $\mathrm{N}$ source was shown in several studies, Fort et al. (2019) recently reported that $\mathrm{NO}_{3}{ }^{-}$accumulation and consumption was positively correlated with Ulva spp. growth, with higher growth rates during the night than during light periods (Fort et al. 2019). In the future, therefore, studies with a greater temporal resolution will be necessary to monitor the dynamics of $\mathrm{N}$ consumption in aquaculture.

Using a closed system under standardised conditions and a controlled microbiome, data by Alsufyani et al. (2017) suggest that depletion of $\mathrm{NO}_{3}{ }^{-}$and the absence of SIs correspond to the change in reproductive phases in U. mutabilis (Alsufyani et al. 2017). However, it is still unclear whether this was due to $\mathrm{N}$ availability or to the absence of $\mathrm{NO}_{3}{ }^{-}$, as other $\mathrm{N}$ sources were not monitored. In the present study, however, the non-limiting resource of $\mathrm{NO}_{3}{ }^{-}$provided from both the entrance (lagoon water) and efflux (fish ponds) (Fig. 4) might be one of the key factors, along with the presumed presence of the SIs provided by $U$. rigida (Stratmann et al. 1996), keeping the algae in the vegetative phase and preventing them from breaking down. Ultimately, this results in the consistent yield of biomass at this specific production site. Elaborated studies are certainly required to verify the 
presence of SIs (i.e. to identify the glycoproteins), which cannot be tested using the bioassays established by Kessler et al. (2018) due to the speciesspecificity of the inhibitors (Stratmann et al. 1996, Kessler et al. 2018).

Although there was a reduction in $\mathrm{PO}_{4}{ }^{3-}$ in the seaweed tanks compared to the filtered water, suggesting some uptake of $\mathrm{PO}_{4}{ }^{3-}$ by the Ulva spp. culture (Tsagkamilis et al. 2010), the level of $\mathrm{NO}_{3}{ }^{-}$remained relatively constant. The fact that, due to different sampling methodologies, water samples were only taken at the sedimentation pond (where some mixing with fish-discharge water can occur) and not at the algae outlet itself may explain the lack of relevant differences before and after algal production in these nutrients. However, this lack of difference may also suggest 2 things: (1) $\mathrm{NH}_{4}{ }^{+}$levels were sufficient to meet algal growth needs and (2) these nutrients are present in excess in the system due to their abundance in the lagoon plus the addition originated in the fish effluent. Overall, the $\mathrm{NO}_{3}{ }^{-}$level was well above the threshold required to prevent reproductive breakdown according to the comparision with data reported by Alsufyani et al. (2017).

Interestingly, in periods of fish absence, the yield and quality of the seaweed biomass dropped, with a negative impact on the profitability of the seaweed farm (ALGAplus unpubl. data). Therefore, we suggest that the IMTA arrangement is necessary for sustainable algal aquaculture as it might reduce fluctuations in nutrients. At the same time, fish farming does not endanger the morphogenetic factors provided by lagoon water. The measurements of $\mathrm{N}$ and $\mathrm{P}$ in the present study are in line with those found in other marine environments. Mean levels of $\mathrm{NO}_{3}{ }^{-}$and $\mathrm{PO}_{4}{ }^{3-}$ concentrations along the drainage network of the northeast Atlantic (NEA) were measured (Desmit et al. 2018). $\mathrm{NO}_{3}{ }^{-}$concentration values were found to fluctuate with the range of $0.45-12.9 \mathrm{mg} \mathrm{N}^{-1}$ (32-921 $\mathrm{mmol} \mathrm{l}^{-1}$ ) in some rivers of the NEA, particularly in Brittany (northern France) and Belgium. Regarding $\mathrm{PO}_{4}{ }^{3-}$ concentration, recorded values were around $0.16 \mathrm{mg} \mathrm{P} \mathrm{l}^{-1}\left(5 \mu \mathrm{mol} \mathrm{l}^{-1}\right)$ in most rivers across the NEA, excluding some Portuguese rivers and the Scheldt and Thames estuaries, where values were as high as $0.65 \mathrm{mg} \mathrm{P} \mathrm{l}^{-1}\left(21 \mu \mathrm{mol} \mathrm{l}^{-1}\right)$ (Desmit et al. 2018).

\subsection{Low metal concentrations in the water}

Potentially toxic elements, such as $\mathrm{Cd}$ and $\mathrm{Pb}$, might affect the normal metabolic function of macroalgae and were measured along with essential ele- ments such as $\mathrm{Cu}, \mathrm{Fe}, \mathrm{Mn}, \mathrm{Mo}$, and Ni. Many trace metals ( $\mathrm{Fe}, \mathrm{Mn}, \mathrm{Zn}, \mathrm{Cu}, \mathrm{Co}, \mathrm{Mo}$, and $\mathrm{Ni}$ ) function as cofactors in metalloenzymes in algae (Sunda 1989). Positive effects on the physiological activity were found, especially for $\mathrm{Zn}$ and $\mathrm{Cu}$, where metal availability correlated with photosynthesis and growth rates (Villares \& Carballeira 2004). However, at elevated concentrations $\left(25-50 \mu \mathrm{g} \mathrm{l}^{-1}\right), \mathrm{Cu}$ negatively affects the growth of $U$. pertusa (Han et al. 2008).

Possibly due to an input of iron in the riverine system, the measured level was higher than the normally low Fe concentration in seawater. Dissolved organic matter can form complexes with iron and might transport it into the IMTA system. The Mn concentration between 5-12 $\mu \mathrm{g} \mathrm{l}^{-1}$ was in the range typically reported in seawater $\left(0.4-10 \mu \mathrm{g} \mathrm{l}^{-1}\right.$; Bruland \& Lohan 2003). The same applied to Mo, which was in the range of about $10 \mathrm{\mu g} \mathrm{l}^{-1}$ (about $100 \mathrm{nmol} \mathrm{l}^{-1}$ ), a typical value for water-soluble molybdate (Bruland \& Lohan 2003). Overall, during the survey, concentrations of total $\mathrm{Cd}, \mathrm{Cu}, \mathrm{Ni}$, and $\mathrm{Pb}$ in the seawater collected at the ALGAplus site did not exceed WHO maximum levels for drinking water (WHO 2008). As metals in the surrounding water are expected to be mainly responsible for metal accumulation in macroalgae, potentially toxic elements were measured in the tissues during the season as part of quality assessment assurance by ALGAplus. The metal contents in algal tissue were always below the following values (in $\mu \mathrm{g} \mathrm{g}^{-1}$ dry weight): $\mathrm{Cd}<0.05, \mathrm{~Pb}<5.0$, and $\mathrm{Hg}<0.1$. Moreover, none of the elements showed variation in values during the year, and the levels are considered safe for use in food (M. H. Abreu unpubl. data). Indeed, tissue values were lower than those recently reported in a European-wide literature study of reported metals in Ulva spp. (Christiansen 2017). The total metal concentration in seawater is sufficient to support extensive cultivation during the season when algae production is carried out but is non-toxic, and the metal tissue concentrations are below the norms.

\section{CONCLUSIONS}

We conclude that the water of the Ria de Aveiro lagoon contains AGMPFs, which are diffusible compounds that can fully induce the morphogenesis of Ulva spp. Our study was a $1 \mathrm{~d}$ snapshot, and future work should include a time course over 1 yr. Fish farming had no adverse effect on the activity of the morphogens and provided nutrients (mainly $\mathrm{NH}_{4}{ }^{+}$) for seaweed production. Essential dissolved nutrients 
such as $\mathrm{NO}_{3}{ }^{-}$and $\mathrm{PO}_{4}{ }^{3-}$ were not depleted, although $\mathrm{NH}_{4}{ }^{+}$was significantly reduced in the algal tanks. Trace metals were available and potentially toxic elements were far below the recommended limits. The permanent circulation of water thus ensures an adequate supply of nutrients. We argue that the presence of morphogens contributes to the sustainable cultivation of Ulva spp. in aquacultures supplied by water from the lagoon and fish ponds. Future studies are recommended to show how these morphogens contribute to Ulva development during the various life cycle phases. Whereas morphogens might also be taken up or metabolised by the organisms present in the habitat, morphogen-releasing bacteria were enriched in Ulva spp. aquacultures. This observation corresponded well to the excess of morphogenetic activity in the water measured. Further studies should now evaluate fluctuations in AGMPF (e.g. morphogens) and life-cycle regulating compounds (e.g. SIs) over the whole year-long growth cycle from seeding until harvesting. In particular, the ongoing identification and characterisation of morphogens will pave the way for further possibilities to control biomass production in aquaculture systems.

Acknowledgements. We thank Georg Pohnert (University Jena), Rui Pereira, Andreia Rego, Sara Coimbra Morgado, and all the ALGAplus team for their great support. This work was supported by 'the German Academic Exchange Service' (Short-Term Research Grant 91608317 to F.G.), 'the Federation of European Microbiological Societies' (FEMS RG 20150085 to F.G.), 'the Islamic Development Bank' (PhD Merit Scholarship 33-R IRN P34 to F.G.), and 'the Deutsche Forschungsgemeinschaft' (CRC 1127 ChemBioSys to J.F.M. and T.W.) and the European Union's Horizon 2020 research and innovation program under the Marie Sklodowska-Curie grant agreement No. 642575 - The ALgal Microbiome: Friends and Foes (ALFF) (to G.C. and T.W.). The authors acknowledge networking support by the COST Action 'Phycomorph' FA1406 through Short Term Scientific Missions (F.G.). The analysis of trace elements in the algal tissue (mentioned in Section 4) was done in the framework of the R\&D co-promotion project POCI-01-0247-FEDER-003419, SHARP-Seaweed for Healthier Traditional Products, cofinanced by the European Regional Development Fund through the Competitive and Internationalization Thematic Operational Program under the Portugal 2020 Program, where ALGAplus is a partner. We thank all 4 reviewers, who contributed to improving the manuscript.

\section{LITERATURE CITED}

Abreu MH, Pereira R, Yarish C, Buschmann AH, SousaPinto I (2011) IMTA with Gracilaria vermiculophylla: productivity and nutrient removal performance of the seaweed in a land-based pilot scale system. Aquaculture 312:77-87
Abreu MH, Pereira R, Sassi JF (2014) Marine algae and the global food industry. In: Pereira R, Neto J (eds) Marine algae, biodiversity, taxonomy, environmental assessment, and biotechnology. CRC Press, Bocca Raton, FL, p 300-319

Ale MT, Mikkelsen JD, Meyer AS (2011) Differential growth response of Ulva lactuca to ammonium and nitrate assimilation. J Appl Phycol 23:345-351

Alsufyani T, Weiss A, Wichard T (2017) Time course exometabolomic profiling in the green marine macroalga Ulva (Chlorophyta) for identification of growth phasedependent biomarkers. Mar Drugs 15:14

Apprill A, Mcnally S, Parsons R, Weber L (2015) Minor revision to V4 region SSU rRNA 806R gene primer greatly increases detection of SAR11 bacterioplankton. Aquat Microb Ecol 75:129-137

* Barott KL, Rodriguez-Brito B, Janouškovec J, Marhaver KL, Smith JE, Keeling P, Rohwer FL (2011) Microbial diversity associated with four functional groups of benthic reef algae and the reef-building coral Montastraea annularis. Environ Microbiol 13:1192-1204

* Bokulich NA, Kaehler BD, Rideout JR, Dillon M and others (2018) Optimizing taxonomic classification of markergene amplicon sequences with QIIME 2's q2-featureclassifier plugin. Microbiome 6:90

* Bolyen E, Rideout JR, Dillon MR, Bokulich NA and others (2019) Reproducible, interactive, scalable and extensible microbiome data science using QIIME 2. Nat Biotechnol 37:852-857

Bruland K, Lohan M (2003) Controls of trace metals in seawater. In: Holland D, Turekian KK (eds) Treatise on geochemistry, Vol 6: the oceans and marine geochemistry. Elsevier, Amsterdam, p 23-47

* Burke C, Steinberg P, Rusch D, Kjelleberg S, Thomas T (2011) Bacterial community assembly based on functional genes rather than species. Proc Natl Acad Sci USA 108:14288-14293

Califano G, Wichard T (2018) Preparation of axenic cultures in Ulva (Chlorophyta). In: Charrier B, Wichard T, Reddy CRK (eds) Protocols for macroalgae research. CRC Press, Boca Raton, FL, p 159-174

Callahan BJ, McMurdie PJ, Rosen MJ, Han AW, Johnson AJA, Holmes SP (2016) DADA2: high-resolution sample inference from Illumina amplicon data. Nat Methods 13: 581-583

Caporaso JG, Kuczynski J, Stombaugh J, Bittinger K and others (2010) QIIME allows analysis of high-throughput community sequencing data. Nat Methods 7:335-336

Caporaso JG, Lauber CL, Walters WA, Berg-Lyons D and others (2011) Global patterns of 16S rRNA diversity at a depth of millions of sequences per sample. Proc Natl Acad Sci USA 108:4516-4522

* Charrier B, Coates JC, Stavridou I (2017) Surfing amongst oil-tankers: connecting emerging research fields to the current international landscape. Trends Plant Sci 22:1-3

Christiansen ER (2017) The potential of Ulva for bioremediation and for food and feed. MSc thesis, Technical University of Denmark, Copenhagen

* Desmit X, Thieu V, Billen G, Campuzano F and others (2018) Reducing marine eutrophication may require a paradigmatic change. Sci Total Environ 635:1444-1466

Echevarréa G, Zarauz N, López-Ruiz J (1993) Study of nitrogen excretion in the gilthead seabream (Sparus aurata L.): influence of nutritional state. Comp Biochem Physiol Part A Physiol 105:17-19 
Fletcher R (1996) The occurrence of 'green tides' — a review. In: Schramm W, Nienhuis PH (eds) Marine benthic vegetation. Springer, Berlin, p 7-43

Fort A, Lebrault M, Allaire M, Esteves-Ferreira AA and others (2019) Extensive variations in diurnal growth patterns and metabolism amongst Ulva spp. strains. Plant Physiol 180:109-123

Føyn B (1959) Geschlechtskontrollierte Vererbung bei der marinen Grünalge Ulva mutabilis. Arch Protistenkd 104: 236-253

Gachon CM, Strittmatter M, Badis Y, Fletcher KI, West PV, Müller DG (2017) Pathogens of brown algae: culture studies of Anisolpidium ectocarpii and A. rosenvingei reveal that the Anisolpidiales are uniflagellated oomycetes. Eur J Phycol 52:133-148

Gao G, Clare AS, Rose C, Caldwell GS (2017) Eutrophication and warming-driven green tides (Ulva rigida) are predicted to increase under future climate change scenarios. Mar Pollut Bull 114:439-447

Ghaderiardakani F, Coates JC, Wichard T (2017) Bacteriainduced morphogenesis of Ulva intestinalis and Ulva mutabilis (Chlorophyta): a contribution to the lottery theory. FEMS Microbiol Ecol 93:fix094

Goecke F, Labes A, Wiese J, Imhoff JF (2010) Chemical interactions between marine macroalgae and bacteria. Mar Ecol Prog Ser 409:267-299

* Grueneberg J, Engelen AH, Costa R, Wichard T (2016) Macroalgal morphogenesis induced by waterborne compounds and bacteria in coastal seawater. PLOS ONE 11: e0146307

Gualtieri P, Barsanti L (2006) Algae: anatomy, biochemistry, and biotechnology. Taylor \& Francis, Boca Raton, FL

Han T, Kang SH, Park JS, Lee HK, Brown MT (2008) Physiological responses of Ulva pertusa and U. armoricana to copper exposure. Aquat Toxicol 86:176-184

Kessler RW, Weiss A, Kuegler S, Hermes C, Wichard T (2018) Macroalgal-bacterial interactions: role of dimethylsulfoniopropionate in microbial gardening by Ulva (Chlorophyta). Mol Ecol 27:1808-1819

Kozhenkova S, Chernova E, Shulkin V (2006) Microelement composition of the green alga Ulva fenestrata from Peter the Great Bay, Sea of Japan. Russ J Mar Biol 32:289-296

Kügler S, Cooper RE, Wegner CE, Mohr JF, Wichard T, Küsel K (2019) Iron-organic matter complexes accelerate microbial iron cycling in an iron-rich fen. Sci Total Environ 646:972-988

Lachnit T, Blümel M, Imhoff JF, Wahl M (2009) Specific epibacterial communities on macroalgae: phylogeny matters more than habitat. Aquat Biol 5:181-186

Lachnit T, Meske D, Wahl M, Harder T, Schmitz R (2011) Epibacterial community patterns on marine macroalgae are host specific but temporally variable. Environ Microbiol 13:655-665

KLiu H, Carvalhais LC, Crawford M, Singh E, Dennis PG, Pieterse CM, Schenk PM (2017) Inner plant values: diversity, colonization and benefits from endophytic bacteria. Front Microbiol 8:2552

Løvlie A (1964) Genetic control of division rate and morphogenesis in Ulva mutabilis Føyn. C R Trav Lab Carlsberg $34: 77-168$

Løvlie A (1968) On the use of a multicellular alga (Ulva mutabilis Foyn) in the study of general aspects of growth and differentiation. Nytt Mag Zool 16:39-49

Maceda-Veiga A, Mac Nally R, de Sostoa A (2018) Environ- mental correlates of food-chain length, mean trophic level and trophic level variance in invaded riverine fish assemblages. Sci Total Environ 644:420-429

Marshall K, Joint I, Callow ME, Callow JA (2006) Effect of marine bacterial isolates on the growth and morphology of axenic plantlets of the green alga Ulva linza. Microb Ecol 52:302-310

* Matsuo Y, Suzuki M, Kasai H, Shizuri Y, Harayama S (2003) Isolation and phylogenetic characterization of bacteria capable of inducing differentiation in the green alga Monostroma oxyspermum. Environ Microbiol 5:25-35

*Matsuo Y, Imagawa H, Nishizawa M, Shizuri Y (2005) Isolation of an algal morphogenesis inducer from a marine bacterium. Science 307:1598

Mineur F, Arenas F, Assis J, Davies AJ and others (2015) European seaweeds under pressure: consequences for communities and ecosystem functioning. J Sea Res 98:91-108

Nielsen MM, Bruhn A, Rasmussen MB, Olesen B, Larsen MM, Møller HB (2012) Cultivation of Ulva lactuca with manure for simultaneous bioremediation and biomass production. J Appl Phycol 24:449-458

* Patarra RF, Carreiro AS, Lloveras AA, Abreu MH, Buschmann $\mathrm{AH}$, Neto AI (2017) Effects of light, temperature and stocking density on Halopteris scoparia growth. J Appl Phycol 29:405-411

Pedregosa F, Varoquaux G, Gramfort A, Michel V and others (2011) Scikit-learn: machine learning in Python. J Mach Learn Res 12:2825-2830

* Provasoli L (1958) Effect of plant hormones on Ulva. Biol Bull (Woods Hole) 114:375-384

Santos SAO, Vilela C, Freire CSR, Abreu MH, Rocha SM, Silvestre AJD (2015) Chlorophyta and Rhodophyta macroalgae: a source of health promoting phytochemicals. Food Chem 183:122-128

* Shpigel M, Guttman L, Shauli L, Odintsov V, Ben-Ezra D, Harpaz S (2017) Ulva lactuca from an integrated multitrophic aquaculture (IMTA) biofilter system as a protein supplement in gilthead seabream (Sparus aurata) diet. Aquaculture 481:112-118

Singh RP, Reddy C (2014) Seaweed-microbial interactions: key functions of seaweed-associated bacteria. FEMS Microbiol Ecol 88:213-230

Smetacek V, Zingone A (2013) Green and golden seaweed tides on the rise. Nature 504:84

Sode S, Bruhn A, Balsby TJ, Larsen MM, Gotfredsen A, Rasmussen MB (2013) Bioremediation of reject water from anaerobically digested waste water sludge with macroalgae (Ulva lactuca, Chlorophyta). Bioresour Technol 146:426-435

Spoerner M, Wichard T, Bachhuber T, Stratmann J, Oertel W (2012) Growth and thallus morphogenesis of Ulva mutabilis (Chlorophyta) depends on a combination of two bacterial species excreting regulatory factors. J Phycol 48:1433-1447

Stratmann J, Paputsoglu G, Oertel W (1996) Differentiation of Ulva mutabilis (Chlorophyta) gametangia and gamete release are controlled by extracellular inhibitors. J Phycol 32:1009-1021

Sunda WG (1989) Trace metal interactions with marine phytoplankton. Biol Oceanogr 6:411-442

Tsagkamilis P, Danielidis D, Dring MJ, Katsaros C (2010) Removal of phosphate by the green seaweed Ulva lactuca in a small-scale sewage treatment plant (Ios Island, Aegean Sea, Greece). J Appl Phycol 22:331-339 
Vesty EF, Kessler RW, Wichard T, Coates JC (2015) Regulation of gametogenesis and zoosporogenesis in Ulva linza (Chlorophyta): comparison with Ulva mutabilis and potential for laboratory culture. Front Plant Sci 6:15

Villares R, Carballeira A (2004) Nutrient limitation in macroalgae (Ulva and Enteromorpha) from the Rías Baixas (NW Spain). Mar Ecol 25:225-243

Weiss A, Costa R, Wichard T (2017) Morphogenesis of Ulva mutabilis (Chlorophyta) induced by Maribacter species (Bacteroidetes, Flavobacteriaceae). Bot Mar 60:197-206

WHO (2008) Guidelines for drinking-water quality: second addendum, Vol 1: recommendations. World Health Organization, Geneva

Editorial responsibility: Alejandro Buschmann,

Puerto Montt, Chile
Wichard T (2015) Exploring bacteria-induced growth and morphogenesis in the green macroalga order Ulvales (Chlorophyta). Front Plant Sci 6:86

* Wichard T, Beemelmanns C (2018) Role of chemical mediators in aquatic interactions across the prokaryote-eukaryote boundary. J Chem Ecol 44:1008-1021

* Wichard T, Oertel W (2010) Gametogenesis and gamete release of Ulva mutabilis and Ulva lactuca (Chlorophyta): regulatory effects and chemical characterization of the 'swarming inhibitor'. J Phycol 46:248-259

* Wichard T, Charrier B, Mineur F, Bothwell JH, De Clerck O, Coates JC (2015) The green seaweed Ulva: a model system to study morphogenesis. Front Plant Sci 6:72

Submitted: August 29, 2018; Accepted: June 7, 2019

Proofs received from author(s): August 5, 2019 